\title{
Doing Archaeology in a Turbulent Time
}

\author{
Akin Ogundiran
}

Accepted: 21 August 2021 / Published online: 4 September 2021

(C) The Author(s), under exclusive licence to Springer Science+Business Media, LLC, part of Springer Nature 2021

By the time this journal issue $(38,3)$ is released, we will be wrapping up the 25th biennial meeting of the Society of Africanist Archaeologists (SAfA), themed "A 20:20 Vision for the Future." For the first time, the society is running its conference entirely online in response to the disruptions caused by COVID-19. The global pandemic forced a one-year delay and converted what should have been a four-day faceto-face meeting in Oxford (UK) into a twenty-threeday online event. Lasting from August 17 through September 28, the conference program will feature 24 sessions, including four plenaries, two roundtable panels, one session for student-related activities, eighteen research panels, and a business meeting. More than 210 presentations will be showcased in the research panels. The conference would not have been possible without the resourcefulness of Peter Mitchell and his organizing committee, the SAfA executive board under Elisabeth Hildebrand's leadership, and the managers of the online meeting platform-Matt Curtis and Susan McIntosh, among others.

The benefits of in-person meetings outweigh those of online interactions but many Africa-based participants would be relieved that they did not have to deal with time-consuming and expensive visa application processes in order to attend the conference in

A. Ogundiran $(\square)$

Department of Africana Studies, The University of North

Carolina at Charlotte, Charlotte, NC 28223, USA

e-mail: Ogundiran@uncc.edu
Oxford. Several Africa-based archaeologists missed some of the recent SAfA conferences in Europe and North America because they were denied visas. In the process, they also parted with the exorbitant and nonrefundable visa application fees. Global disparities in knowledge production will remain intact until Western state actors dismantle the roadblocks they have created to prevent many Africa-based scholars from traveling to European and North American countries for professional conferences. In contrast, scholars from the global north have nearly unfettered access to Africa.

The fact that we are participating in the SAfA conference from the comfort of our homes and offices is a stark reminder that the COVID-19 pandemic is still with us. The appearance of more potent variants of the virus, especially delta (B.1.617.2), has complicated the situation as new infection hotspots emerge or rekindle in different parts of the world. Africa is not exempted from the worldwide human and economic costs of the pandemic. It may be experiencing more hardship than other geographical zones, due more to stringent lockdown policies to curb the pandemic than to infection and illness (Anyanwu \& Salami, 2021). African Development Bank (2021) estimates that about 39 million Africans could fall into extreme poverty in 2021 from the socioeconomic impacts of the pandemic: job loss, revenue/income declines, consumer price increases, supply-chain disruptions, business closure, and increase in the cost of doing business. There are also social deficits from 
prolonged school closure, which exceeded 100 days for many African countries in 2020. Many of those locked out of school will never return to the classroom. This scenario will have long-term impacts on human development, such as increased levels of learning poverty (defined by World Bank as the percentage of 10-year-old children who cannot read and understand a simple story), juvenile misdeeds, and teenage pregnancy. Most archaeologists of Africa work with populations that are most vulnerable to the effects of the pandemic. Many of those populations are also relatives.

As if this is not enough, many countries in Africa and elsewhere are currently gripped by conflicts, political instability, and a restless citizenry responding to conditions of social inequalities that preceded the pandemic and are now worsened by it. At the same time, climate change, dwindling natural resources, population displacement, and migration are stoking social conflicts, intensifying environmental degradation, and putting archaeological sites and other forms of heritage, including human resources and knowledge systems, at risk (Brooks et al., 2020). The recently released climate report of the United Nation's Intergovernmental Panel on Climate Change (IPCC) illustrates the urgency of the climate crisis (IPCC, 2021). The panel noted that "human influence has warmed the climate at a rate that is unprecedented in at least the last 2000 years." Most importantly, the experts are unequivocal that human influence has accelerated warming and rapid changes in the atmosphere, ocean, cryosphere, biosphere, and land since around AD 1750. IPCC's unambiguous conclusions that human activities are responsible for ongoing extreme weather events, such as heatwaves, droughts, and excessive rainfall, and its policy recommendations on how to reverse the dire situation have been described as "a wake-up call for immediate climate action" (reliefweb, 2021).

Most archaeologists will not be surprised by United Nation's IPCC 2021 report. The effects of climate change on biodiversity loss, destruction of archaeological sites, food insecurity, population displacement, and sociopolitical conflicts are recognizable in many of our research areas (e.g., Douglass et al., 2019; Logan et al., 2019). Hence, archaeologists have been at the forefront of calling attention to the climate crisis and using archaeology's long-term perspectives as a framework for finding sustainable solutions (e.g., Chase \& Scarborough, 2014; Rick \& Sandweiss, 2020). Archaeologists have drawn our attention to how several African communities use their knowledge systems to create resilient responses to climate change and its fallouts. But some of those knowledge systems have also been compromised and degraded by the legacies of colonialism, postcolonial states, and globalization (e.g., Davies, 2012; Douglass \& Cooper, 2020; Lane, 2015). As a result, most of these local agencies of resilience cannot cope with the effects of capitalist agriculture, industrial-scale production, and rapid urban growth around them. There are also cases of desperation, whereby atrisk communities eking out a living from dwindling resources have unwittingly desecrated sacred groves, destroyed archaeological sites, and exacerbated biodiversity loss. Even those sites under institutional protection are not often spared from destruction in countries with weak government monitoring systems.

The ongoing civil war in Ethiopia, recent uprising in South Africa, and continued insecurity in the Sahara-Sahel axis, Nigeria, Niger, Chad, and Cameroon, among others, have also elevated the hardship for millions of people and shut out or reduced archaeological research in active conflict zones. In response to the ongoing civil war in Ethiopia, many scholars have invoked what Edward Kissi $(2016,2021)$ calls the "moral conversation about human dignity" to appeal for restraint on the part of the state actorsespecially between the Federal Government of Ethiopia and the Regional Government of Tigray. Several African and Africanist archaeologists, led by Federica Sulas and Michael J. Harrower, have been at the forefront of this conversation. On the eve of the outbreak of the civil war in November 2020, Ibrahima Thiaw, Innocent Pikirayi, Alfredo González-Ruibal, and Amanda Esterhuysen, and I collaborated with Sulas and Harrower in preparing the document titled "Open Letter About Violent Conflict and Heritage in Ethiopia" (Sulas et al., 2020). The letter invoked the moral argument about the sanctity of human lives and cultural heritage and appealed to both sides of the conflict to de-escalate the imminent military confrontation. The last two paragraphs of the open letter stated:

In our view, any person killed, injured, or forced to flee is a loss of our collective humanity and heritage of global significance. 
We therefore call upon cultural and heritage organizations to raise awareness about threats to humanity and heritage and to take action, both as organizations and as individual members, to urge de-escalation, ceasefire, and protection of people, their past, and their future. Efforts to these ends could include: contacting government representatives in one's own country, supporting humanitarian aid organizations, writing and communicating through media and social media, or contributing to petitions and open letters.

More than 260 people have since signed the open letter, also endorsed by the World Archaeology Congress. The appeal letter did not de-escalate the conflict, and all that we were concerned about has happened and is still happening. Since November 2020, nearly two million people have been displaced in Ethiopia, according to the International Organization for Migration, and famine is of elevated concern for northern Ethiopia in the coming months. In the meantime, the regional implications of the conflict are already being felt in Eritrea and Sudan. The Sulas-Harrower-led appeal was not the only one by academic groups. Twenty-three researchers and fellows of the Hiob Ludolf Centre for Ethiopian and Eritrean Studies at Universität Hamburg were also moved to launch "An appeal for the salvation of the cultural heritage of Tigray" on January 13, 2021, in response to the reports of the heavy toll of the conflict on the civilian population. The appeal for restraint, signed by seventy people, also responded to reports (though not all verified) that several historical sites in the Tigray region, including "the church at Yeha, alNajashi Mosque, the church of Maryam Dengelat, the monastery of Dabra Abbay, the monastery of Dabra Dammo, and even St Mary Cathedral in Aksum" have suffered damages from the war, and that the manuscripts from Tigrayan churches and monasteries were being looted (Hiob Ludolf Centre, 2021). Our colleagues who initiated or signed both appeals were not under any illusion that their efforts would magically turn things around, but their hope (and only hope, I must stress) is that their contributions to the public awareness about the conflict would touch the moral conscience of state and institutional actors in Ethiopia and elsewhere and move them to stop the carnage. At the time of this writing, we are still hoping, and many of us continue to raise awareness about the impacts of the violence on Ethiopian peoples and their neighbors (e.g., Kissi, 2021).

The violence that immediately followed the incarceration of former president Jacob Zuma of South Africa caught the world by surprise. The scale of rioting, looting, and destruction that also led to the death of about 337 people in KwaZuluNatal and Gauteng provinces between July 9th and 17 th has been described as the most important test of the 24-year old democracy in South Africa. Many pundits and scholars have offered a wide range of reasons for the mayhem. Whatever the causes, the uprising is a sad reminder of what can happen whenever a segment of the society loses faith in the state, and the prevailing conditions of hopelessness make them complicit in destroying their community. The archaeology of social complexity typically focuses on the grandeur of monuments, state formation, long-distance trade, hierarchies, technology, production, lavish consumption, and elaborate material life. Only a few studies have explored poverty and marginalization as a lived experience of complexity and modern capitalism (e.g., Orser, 2011; Richard, 2011). It is important to pay more attention to the roles that social inequality and discontentment (beyond poverty) might have played in the past as a source of instability for different scales of social complexity. As my study of nineteenth-century Yoruba states has shown (Ogundiran, 2020, p. 378), the consequences can be dire when deep, multigenerational structural inequality and little hope for change make marginalized populations lose confidence in their society.

Global and regional inequalities affect how we do archaeology, an issue that was recently discussed on SAfA's Listserv about collaborative research and publication between foreign-based and Africa-based archaeologists (April 2021). Achieving equity over access to research and publication resources in African archaeology is also at the forefront of the African Oxford Initiative (2021) Globinar series, three of which were held between January and April this year. The crux of the series is that increasing global inequalities, compounded by the COVID-19 pandemic and institutions of racism and white supremacy ideology, dictate that archaeologists reexamine their practices, go beyond colonial epistemologies, 
and create new "models of alternative knowledge that have the potential to contribute towards sustainable development" in Africa. These highlyspirited and highly-charged conversations must be followed with concrete action plans to achieve the changes we want. The discussions should also go beyond speaking to the metropolises of the former European empires and their appendages. Rather, to begin the difficult journey of decolonization, we must have the humility to accept that this is not an easy process considering how profoundly colonized African institutions remain even when they are mostly run by Africans. Hence, to begin on the path of Africanizing and decolonizing African archaeology, archaeologists in Africa must engage one another within each country, at the regional levels, and across the regions, on priorities that include systemic revisioning of curricula, research agendas, publication, and ownership of the process of knowledge production (Chirikure, 2021, this issue; Ly, 2018). These dialogues must transcend the legacies of colonial boundaries and engage people in other disciplines.

Access, or lack of access, to relevant literature and funding shapes how research projects are conceptualized and determines the scope and implementation of such projects. For example, many Africa-based colleagues fund field research and laboratory projects with their meager income (see Opadeji, 2021, this issue). It is not unusual for graduate students to rely on paltry family resources to conduct fieldwork. In those circumstances, the cost of even one AMS date is beyond the reach of most Africa-based scholars. Also, due to resource scarcity and resource mismanagement, many African institutions may put subscriptions to archaeology journals at the bottom of their priorities, making it difficult for Africa-based scholars to access current literature in their field and publish in high profile journals (also see Mekonnen et al., 2021). We hope the ongoing discussions by some SAfA members on setting up a fund to assist African colleagues with radiometric dating will soon begin to bear fruits. In the meantime, I was in a year-long dialogue with the senior editorial managers of Springer Nature (the publisher of African Archaeological Review) about obtaining complimentary subscriptions to the journal for several African universities. The conversation led to the discovery that Springer Nature participates in the Research4Life program, which aims to provide institutions in low-income countries with access to peer-reviewed content. Through the program, Springer Nature offers those institutions free online access to all its journals, including $A A R$ . Most African countries qualify for this program, and many institutions on the continent are registered members of Research4Life (https://www.research41 ife.org/access/institutions-registered/). Colleagues in African universities whose institutions are already registered should be able to access $A A R$ issues from Research4Life. If not, they should contact their university librarian to register for the program. This initiative contributes to leveling the playing field of scholarship, and I hope many colleagues and their institutions will take advantage of the opportunity.

Finally, this issue of AAR covers the wide range of themes that makes African archaeology a unique and exciting field. The research and report articles, the Usable Pasts Forum, and book reviews include topics dealing with the emergence of cognitively modern humans, social complexity, trading networks, and some of the consequences of the entanglement of Africa in the web of the early modern world. Notably, the third in the Usable Pasts Forum series of the journal, guest-edited by Shadreck Chirikure, explores the challenges and opportunities associated with the World Heritage Site inscription and how to maximize the tourism benefits of heritage sites for local communities. The contributors have provided important insights that are contextual and based on case studies. We hope policymakers and heritage managers, as well as archaeology practitioners and students, would find the forum helpful. On this note, many thanks to Associate Editor Cameron Gokee for steering the logistical process of the forum, from conceptualization to publication.

So, the incremental work of expanding African archaeological knowledge continues despite all the odds. On behalf of the editorial board, I express our gratitude to the authors, reviewers, and readers of the African Archaeological Review. We have not chosen this turbulent time; it has chosen us. Our resourcefulness, collaboration, and compassion for one another will see us through it and hopefully lead us to a better future. 


\section{References}

African Development Bank (2021). African Economic Outlook 2021-from debt resolution to growth: The road ahead for Africa. African Development Bank.

African Oxford Initiatives (2021). Future of Archaeology in Africa \& the Diaspora. https://www.afox.ox.ac.uk/afoxevents. Accessed 10 Aug 2021.

Anyanwu, J. C., \& Salami, A. O. (2021). The impact of COVID-19 on African economies: An introduction. African Development Review, 33(S1), S1-S16. https://doi.org/ 10.1111/1467-8268.12531.

Brooks, N., Clarke, J., Ngaruiya, G. W., \& Wangui, E. E. (2020) African heritage in a changing climate. Azania: Archaeological Research in Africa, 55(3), 297-328. https://doi.org/10.1080/0067270X.2020.1792177.

Chase, A., \& Scarborough, V. (2014). Diversity, resiliency, and IHOPE-Maya: Using the past to inform the present. Archeological Papers of the American Anthropological Association, 24, 1-10.

Chirikure, S. (2021). UNESCO and heritage tourism in Africa. African Archaeological Review, 38(3). https://doi.org/10. 1007/s10437-021-09454-6.

Davies, M. I. J. (2012). Some thoughts on a "useable" African archaeology: Settlement, population and intensive farming among the Pokot of northwest Kenya. African Archaeological Review, 29(4), 319-354.

Douglass, K., Walz, J., Quintana Morales, E., Marcus, R., Myers, G., \& Pollini, J. (2019). Historical perspectives on contemporary human-environment dynamics in southeast Africa. Conservation Biology, 33, 260-274.

Douglass, K., \& Cooper, J. (2020). Archaeology, environmental justice, and climate change on islands of the Caribbean and southwestern Indian Ocean. Proceedings of the National Academy of Science, 117, 8254-8262.

Hiob Ludolf Centre for Ethiopian and Eritrean Studies at Universität Hamburg (2021). An appeal for the salvation of the cultural heritage of Tigray. https://www.aai. uni-hamburg.de/en/ethiostudies/news/appeal2021.html. Accessed 6 Aug 2021.

IPCC (2021). Climate Change 2021: The Physical Science Basis. Contribution of Working Group I to the Sixth Assessment Report of the Intergovernmental Panel on Climate Change [Masson-Delmotte, V., P. Zhai, A. Pirani, S. L. Connors, C. Péan, S. Berger, N. Caud, Y. Chen, L. Goldfarb, M. I. Gomis, M. Huang, K. Leitzell, E. Lonnoy, J. B. R. Matthews, T. K. Maycock, T. Waterfield, O. Yelekçi, R. Yu and B. Zhou (eds.)]. Cambridge University Press. In Press.

Kissi, E. (2016). Obligation to prevent (O2P): Proposal for enhanced community approach to genocide prevention in Africa. African Security Review, 25(3), 242-257.

Kissi, E. (2021). Africa can prevent Ethiopia from going down Rwanda's path: Here's how. The Conversation. https://theco nversation.com/africa-can-prevent-ethiopia-from-going-downrwandas-path-heres-how-165254. Accessed 2 Aug 2021.

Lane, P. J. (2015). Archaeology in the age of the Anthropocene: A critical assessment of its scope and societal contributions. Journal of Field Archaeology, 40(5), 485-498. https://doi.org/10.1179/2042458215Y.0000000022.

Logan, A. L., Stump, D., Goldstein, S. T., Orijemie, E. A., \& Schoeman, M. H. (2019). Usable Pasts Forum: Critically engaging food security. African Archaeological Review, 36(3), 419-438. https://doi.org/10.1007/ s10437-019-09347-9.

Ly, M. A. (2018). Reconstruire l'anthropologie en Afrique postcoloniale : enjeux, orientations et méthodes d'une nouvelle offre de formation doctorale (Reconstructing postcolonial anthropology: challenges, directions, and methods for a new doctoral program). Presses Universitaires de Dakar.

Mekonnen, A., Downs, C., Effiom, E. O., Razafindratsima, O., Stenseth, N. C., \& Chapman, C. A. (2021). What costs half a year's pay for African scholars? Open Access. Nature, 596, 189. https://doi.org/10.1038/d41586-021-02173-7.

Ogundiran, A. (2020). The Yoruba: A new history. Indiana University Press.

Opadeji, O. A. (2021). Later Stone Age occupation on Iresi Hills: A new dated context in southwest Nigeria. African Archaeological Review, 38(3). https://doi.org/10.1007/ s10437-021-09439-5.

Orser, C. E. (2011). The archaeology of poverty and the poverty of archaeology. International Journal of Historical Archaeology, 15(4), 533-543.

reliefweb (2021). Latest IPCC report is a wake-up call for immediate climate action. https://reliefweb.int/report/ world/latest-ipcc-report-wake-call-immediate-climateaction. Accessed 20 Aug 2021.

Richard, F. G. (2011). Materializing poverty: Archaeological reflections from the postcolony. Historical Archaeology, 45(3), 166-182.

Rick, T. C., \& Sandweiss, D. H. (2020). Archaeology, climate, and global change in the Age of Humans. Proceedings of the National Academy of Science, 117(15), 8250-8253. https://doi.org/10.1073/pnas.2003612117.

Sulas, F., Harrower, M. et al. (2020). Open letter about violent conflict and heritage in Ethiopia. https://www.africanarchaeol ogy.org/news/2020/12/2/archaeologists-and-cultural-herit age-experts-and-advocates-distributeopen-letter-about-viole nt-conflict-and-heritage-in-ethiopia. Accessed 6 Aug 2021.

Publisher's Note Springer Nature remains neutral with regard to jurisdictional claims in published maps and institutional affiliations. 